Ethiopian Journal of Environmental Studies \& Management 8(3): 342 - 350, 2015.

ISSN:1998-0507

doi: http://dx.doi.org/10.4314/ejesm.v8i3.11

Submitted: January 28, 2015

Accepted: April 07, 2015

\title{
TECHNICAL EFFICIENCY AMONG CASSAVA FARMERS IN IKENNE LOCAL GOVERNMENT AREA OF OGUN STATE, NIGERIA
}

\author{
MAKINDE, Y.O., 1 *BALOGUN, 0.L., ${ }^{2}$ BELLO, A..T² AND AFODU, 0.J. ${ }^{2}$ \\ ${ }^{1}$ Department of Nutrition and Dietetics \\ ${ }^{2}$ Department of Agricultural Economics \& Extension, School of Agriculture and Industrial \\ Technology, Babcock University, Ilishan Remo, Ogun state, Nigeria.
}

\begin{abstract}
Cassava has played and continues to play a remarkable role on the agricultural stage of Nigeria. The inability of the country meeting existing demand has been traced to resource use efficiency of the farmers. The study evaluates the technical efficiency among cassava farmers in Ikenne Local Government Area of Ogun State, Nigeria. Primary data employed in the study were obtained from 155 cassava farmers selected through a 2-Stage sampling technique. Data were analyzed using descriptive statistics and stochastic frontier model. Results showed that the return to scale was 1.814. Cassava stem cuttings (0.484), quantity of fertilizer used (0.614) and the farm size (0.427) significantly ( $p \leq 0.05)$ affected cassava production. Age and farming experience contributed to technical inefficiency while cassava stem cuttings, quantity of fertilizer used and the farm size enhanced technical efficiency. Efficiency of cassava growers ranged between 35.1 and 97.0 with a mean of 68.5. It was concluded that cassava production was highly profitable and farmers operated with maximum efficiency given the current technology. The study recommends increased area under cultivation and improved cassava varieties coupled with other inputs to boost to productivity of farmers.
\end{abstract}

Key Words: Technical efficiency, Cassava farmers, Demand, Farm size, Profitable

\section{Introduction}

Agriculture continues to be a strategic sector in the development of most countries in sub-Sahara Africa. It employs about $40 \%$ of the active labor force globally (World Bank, 2002). In Nigeria, agriculture provides food for the teeming population and contributes about $33 \%$ to the Gross Domestic Product (GDP) of the nation (Bureau of African Affairs, 2010). The sector employs about one-third of the total labor force and provides a livelihood for the bulk of the rural populace (FMARD, 2006). The performance of small holding farms in Nigeria is observed to be unsatisfactory. The agricultural sector of Nigeria has failed to keep pace with the demand of households and industries for farm produce as food or raw materials (Nwaiwu et al., 2010).

Food is one of the basic needs of man but its provision is not always adequate for all nations especially in developing countries. This insufficiency of food had led man to better ways of producing it. Nigeria is now diversifying its economic resources and efforts are being intensified to revamp the agricultural sector once again in order to achieve sustainable economic development through policies aimed at increasing agricultural production for instance cassava products for both local use and export trade. (RMRDC, 2004). Nigeria is the world's largest producer of cassava, 
with about 54.0 million metric tonnes and ranks $2^{\text {nd }}$ after yam in extent of production among the root and tuber crops of economic value in Nigeria (FAOSTAT, 2013).

According to Food and Agriculture Organization of the United Nations database (FAOSTAT, 2013), Nigeria is the largest producer of the crop with 36.8 , 42.5, 52.4 and 54.0 million metric tonnes in 2009, 2010, 2011 and 2012 respectively. About $90 \%$ of Nigeria's cassava production is however, consumed locally as food (Awoyinka, 2009). Nigeria needs yet to fully harness the economic potentials of cassava which would translate to higher ranking next to petroleum as major contributor to the Gross Domestic Product (GDP). For this to be achieve cassava farmers production efficiency and profit margins needs to be improved.

Cassava (Manihot esculenta Crantz) is one of the most important crops in Nigeria as well as in Africa because it serves as a major source of carbohydrate (Nweke et al., 1994; Nandi et al., 2011). Cassava can be grown and stored in the field in all seasons because it is relatively less sensitive than most crops to environmental changes (IITA, 1999). The significance of cassava cannot be undermined as cassava is a crop which serves both as food and feed (Chukwuji, 2006). The cassava cultivation has been neglected for a long time in Nigeria, but now it has become a key food security crop because it's many comparative advantages over others cultivations like cereals. It is highly adaptable to marginal soils and erratic rainfall conditions. It is rich in carbohydrate allowing for multiplicity of use, it is highly resistant to pests and diseases and it can maintain constant supply throughout the year. (Nwaiwu et al., 2004). It is an important food and cash crop in several tropical African countries, especially Nigeria where it plays a principal role in the food economy (Agwu, 2007).
Simonyan et al. (2010) stated that Nigerians are poor and hungry despite efforts made by various governments in improving agricultural productivity and efficiency of the rural farmers who are the major stakeholders of agricultural production. This effort is geared towards programs that will result to effective production. One of such programs is the Root and Tuber Expansion Program, aimed at increasing root and tuber crops production. Specifically, in the area of Cassava, a Presidential Initiative on Cassava Production and Export was unfolded by Nigerian government in 2002 . The initiative was aimed at using Cassava production as the engine of economic growth for the nation. Based on this, in 2005, the Federal Government of Nigeria promulgated a law, making it mandatory for bakers to use composite flour of $10 \%$ Cassava and $90 \%$ wheat for bread production. The initiative seeks to generate about US\$5 billion as export revenue in 2007. Since then, the demand for Cassava products globally increased which has led to an increase in its cultivation, but not enough to curb demand, thereby, putting a lot of pressure on production of Cassava. Olukosi (1999) suggested that access to adequate food by all members of the household and the entire nation at large at all times, for the maintenance of a healthy and active life is one of the major ways of fighting food insecurity in everywhere on the world. Despite the involvement of many rural farmers in the agricultural production, several odds however still work against their efforts to produce abundant food for the nation and live a better life.

The passion for cassava production has increased over the years rapidly as a result of the awareness of the importance of this practice to individuals and the economy at large, as well as the advantages attached to it. Based on this nexus, this study examines technical efficiency among cassava farmers in Ikenne Local Government area of Ogun 
State, Nigeria by answering the following questions: what are the factors determining technical efficiency of cassava farmers and their level of technical efficiency in the study area. The main objective of the study is to examine the technical efficiency among cassava farmers in Ikenne Local Government Area of Ogun State, Nigeria. The specific objectives are to determine the socio-economic characteristic of cassava farmers and to know the determinants of technical efficiency of the cassava farmers in the study area.

\section{Materials and Methods}

\section{Study Area}

The study was conducted in Ikenne Local Government Area (LGA) of Ogun
State, which has it's headquarter at Ikenne Remo. The Local Government Area is bounded $4 \mathrm{~km}$ to the East by Odogbolu Local Government Area (LGA), 5km to the South by Ayepe, $10 \mathrm{~km}$ to the North east by Irolu, $4 \mathrm{~km}$ to the North by Ilara, $2 \mathrm{~km}$ to the East by Ilishan and $7 \mathrm{~km}$ to the West by Sagamu. The local government is located along the transitional forest zone of southern Nigeria and Guinea savannah. It is situated 235.2 meters above sea level, has an annual rainfall of $1200 \mathrm{~mm}, 65 \%$ mean relative humidity and $21.4^{\circ}$ mean temperature. Figure 1 shows the map of Ikenne local Government Area in Ogun state, Nigeria.

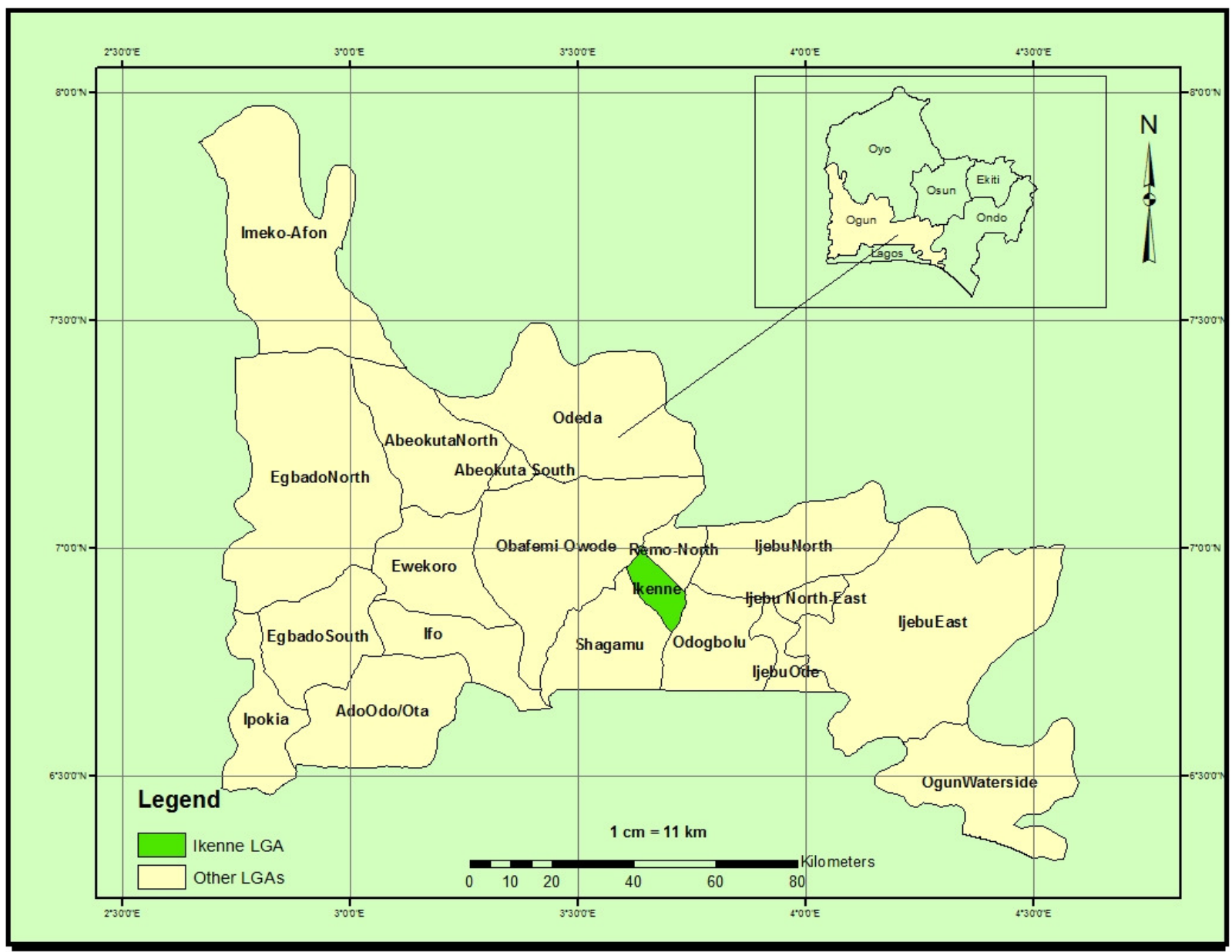

Figure 1: Map of Ogun state showing Ikenne local Government Area 


\section{Sampling Procedure}

Data for this study were mainly primary data which were collected with the aid of questionnaires applied to cassava farmers in the study area. A two stage random sampling technique was adopted for this study. In the first stage were randomly selected five towns from the Local Government Area (LGA). The next stage of the sampling involved the random selection of 31 farmers from each of the selected towns in the Local Government Area (LGA), to give a total of 155 farmers which were used for the analysis. Analytical tools used in the study were: descriptive statistics and stochastic frontier model

i) Descriptive Statistics

Descriptive statistics such as mean, percentage and frequency

ii) Stochastic Frontier Production Function

The model of the stochastic frontier production for the estimation of technical efficiency is specified as:

$Y=f\left(X_{i j} \beta\right)+e_{i}$

$\mathrm{e}_{\mathrm{i}}=\mathrm{V}_{\mathrm{i}^{-}} \mathrm{U}_{\mathrm{i}}$

Where $\mathrm{Y}$ is output of the farmer $1, \mathrm{X}_{\mathrm{i}}$ is input, $\beta$ is a vector of parameters to be estimated (including the efficiency parameter). The disturbance term $i e$ consist of two components $\mathrm{V}_{\mathrm{i}}$ and $\mathrm{U}_{\mathrm{i}}$.

Where $V_{i}-N\left(0, \sigma^{2}\right)$ and $\mathrm{Ui}$ is a one-sided error term. The two errors $V_{i}$ and $U_{i}$ are assumed to be independently distributed. The term $V_{i}$ is the symmetric component and permits random variation of the production function across farms; while it also captures factors outside the control of the farmer. A one-sided component $\left(\mathrm{U}_{\mathrm{i}}>0\right)$ reflects technical efficiency relative to the stochastic frontier. If $\mathrm{U}_{\mathrm{i}}=0$, production lies on the stochastic frontier, while if $\mathrm{U}_{\mathrm{i}} \square \square \square$, production lies below the frontier and is inefficient

The error term is assumed to follow one of three possible distributions (Bauer, 1990) i) half-normal as $\mathrm{U} / \mathrm{N}\left(0, \sigma u^{2}\right)$

ii) exponential as EXF $\left(\mu a u, \sigma u^{2}\right)$

iii) truncated normal at zero $N \sim\left(\mu \omega, \sigma u^{2}\right)$

It follows;

$\sigma^{2}=\sigma_{v}=\sigma_{u^{2}} \quad$.............................. 2

where

$\sigma=\left[\sigma_{v^{2}}+\sigma_{u^{2}}\right]^{1 / 2}$

In accordance with Jondrow et al. (1982), the Technical Efficiency (TE) of the individual farmer is calculated as the expected values of $\mathrm{Vi}$ conditional on

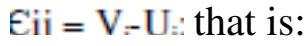

Following Jondrow et al. (1982), the Technical Efficiency (TE) of the individual farmer is calculated as the expected values of $\mathrm{V}_{\mathrm{i}}$ conditional on $\mathrm{Eii}=\mathrm{V}-\mathrm{U}$ : that is:

$\mathrm{E}\left(u_{i} / \varepsilon_{i}\right)=\frac{\sigma_{x-\sigma_{y}}}{\sigma}\left[\frac{f\left(s_{i}^{2} / \sigma\right)}{1-F\left(\varepsilon_{i}^{2} / \sigma\right)}-\frac{\varepsilon_{i}^{2}}{\sigma}\right] \ldots \ldots . .3$

Where $\mathrm{E}$ is the expectation of the farm operator, $\mathrm{F}^{*}$ and $f^{*}$ are the values of the standard normal density and distribution functions respectively. Measures of technical efficiency (TE), technical efficiency is then calculated as:

So that $0 \leq \mathrm{TE} \leq 1$.

$\mathrm{TE}=\exp \left(-\mathrm{E}\left\langle u_{i} / \varepsilon_{i}\right\rangle ; \mathrm{i}=1\right.$ 4

The empirical model of the stochastic production frontier is specified as

$\mathrm{Yi}=\beta_{0}+\beta_{1} \operatorname{In} X_{1}+\beta_{2} \operatorname{In} X_{2}+\beta_{3} \operatorname{In} X_{3}+$ $\beta_{4} \operatorname{InX}_{4}+\beta_{5} \operatorname{In} X_{5}+\beta_{6} \operatorname{In} X_{6}+$ Vi- Ui ...... 5 $\mathrm{Y}=$ Output of the farmers in $\mathrm{kg}$.

$\mathrm{X}_{1}=$ Hire Labour input use in production in man-day

$\mathrm{X}_{2}=$ Farm Size in (ha).

$\mathrm{X}_{3}=$ Family Labour in (Man-day)

$\mathrm{X}_{4}=$ Fertilizer in $(\mathrm{kg})$

$\mathrm{X}_{6}=$ Cassava stem in (cuttings)

In's = Parameters to be estimated.

Ln's = Natural Logarithms

$\mathrm{Vi}=$ The symmetric component that captures random error associated with 
random factor under the control of cassava farmers.

$\mathrm{Ui}=$ The asymmetric error component represents the deviation from the frontier production (the technical inefficiency).

The efficiency model:

$\mathrm{Ui}=\alpha_{0}+\alpha_{1} \mathrm{Z}_{1} \mathrm{i}+\alpha_{2} \mathrm{Z}_{2} \mathrm{i}+\alpha_{3} \mathrm{Z}_{3} \mathrm{i}+\alpha_{4} \mathrm{Z}_{4} \mathrm{i}+$

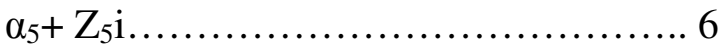

Where:

$\mathrm{U}_{\mathrm{i}}=$ Technical efficiency of the cassava farmers

$\mathrm{Z}_{1}=$ Age of farmers (years).

$\mathrm{Z}_{2}=$ Household size

$\mathrm{Z}_{3}=$ Farming experience (years).

$\mathrm{Z}_{4}=$ Years spent in school (years).

$\mathrm{Z}_{5}=$ Extension contacts $(\mathrm{Yes}=1, \mathrm{No}=0)$

$\alpha_{i}^{\prime} s=$ Parameters to be estimated.

\section{Results and Discussion}

The socioeconomic characteristic of the cassava farmers in the study area is presented in Table 1. The result shows that most the farmers $(58.7 \%)$ were male while the remaining was female. The result indicated that male dominated cassava production in the study area. The result disagrees with Adebisi et al. (2012) and Owombo (2012) female farmers dominated food crop production in south-western Nigeria. The reason for this might be due to the less involvement of the female farmers in cash crop production than women and the greater concern of the women for household consumption. The distribution of the farmers by age shows that $31.6 \%$ of the cassava farmers were less than 30 years while $3.8 \%$ were above 61 years. Majority $(64.6 \%)$ of the farmers were in age range 30-60 years while the mean age of farmers was 39.8 years. This is the active productive age. This is an indication that majority of the farmers in the study area are still in their working age. Most operations in cassava cultivation, such as land clearing, tilling, weeding and harvesting, require a lot of strength and energy. Thus, only those farmers within the productive age group are likely to possess the necessary strength to carry out these operations. The result indicates that $69.7 \%$ of cassava farmers in the study area cultivated less than one hactare of land. This implies that majority of cassava farmers in the area operate on small to medium scale. This corroborates the findings of (Akatugba-Ogisi,1994; Ogisi et al., 2013) that farm sizes in Nigeria are small and in most cases fragmented. The mean average size of 6.0 observed among the cassava farmers is below the acclaimed average household size of about 8 which is more common in rural communities in Nigeria. About $20.6 \%$ of the farmers had farming experience of less than 6 years. Those with farming experience of 6 years and above comprise $79.4 \%$. This implies that cassava farming is not only an occupation but a way of life of the people in the study area. The farmers have sufficient agricultural experience, which could explain the high level of technical efficiency of farmers. The result collaborates Nandi et al. (2011) that most cassava farmers in Nigeria have been cultivating cassava for years. Most of cassava farmers are married and were educated enough to be able read and write. The literacy level here implies that it may be easier for them to adopt and practice innovations in farming. The distribution of farmers by extension contact revealed that $12.9 \%$ of the respondents had contact with extension agent.

Table 2 shows the results of stochastic frontier model of cassava farmer. The maximum likelihood estimate of the CobbDouglas production function shows that the Lambda and Gamma values were 5.226 and 0.328 respectively significant at $5 \%$ level. The values are significantly different from zero suggesting that the model is a good fit. The return to scale of 1.8143 implies an increasing return to scale. Any additional input will lead to more than proportionate change in the output. This shows that the farmers are in stage 1 of production 
function. The results indicated that three significant variables in this model are cassava stem cuttings, quantity of fertilizer used and the farm size $(\mathrm{p}<0.05)$. The coefficient of cassava stem cuttings (0.484) is positive and inelastic. This implies that increasing the cassava stem cuttings by one kilogram will bring about $48.7 \%$ increases in output of the cassava growers in the area. Similarly, the quantity of fertilizer used by farmer (0.614) has positive relationship with technical efficiency. This implies that increasing the quantity of fertilizer used will increase output by $61.4 \%$. In the case of land size, the coefficient is also positive and inelastic. The result shows one hectare increase in farm size grown to cassava increased technical efficiency cassava farmer by $42.7 \%$. For farm specific characteristics, the only significant variables are age $(\mathrm{p}<0.10)$ and farming experience $(\mathrm{p}<0.05)$. Only age is positive meaning that they contribute to technical inefficiency in cassava production in the area. This might be as farmers become older his willingness to adopt improved technology that can enhance their efficiency will decrease. In case of farming experience, past bad experience may also make farmer to be skeptical about adoption new improved technology that can increase their efficiency. It is shown in Table 3 that efficiency of the cassava growers ranged between 35 and $97 \%$ with a mean of $68.5 \%$. Thus, they are all operating at low levels of efficiency given the cassava production technology available to them. This may be a contributing factor to the low level of cassava production in the area. The mean technical efficiency estimated was $\mathrm{TE}=0.685$ in Table 3 , indicating that the realized output could be increased by about $31.5 \%$ by adopting the practices of the best cassava farmers.

\section{Conclusion and Recommendations}

Majority of the cassava farmers were married with age between 41 to 50 years.
The farmers were educated with household size 6 persons. Few of the farmers had access to extension agent and most of them had been in cassava production business for over 6 years. The results of the maximum likelihood estimates of the parameters in the Cobb-Douglas production function for the efficiency of the sampled cassava farmers revealed that the cassava cuttings, quantity of fertilizer used and the farm size significantly determined cassava farmer's technical efficiency. The results of this study showed that majority of cassava farmers were technically efficient, given the technology they use. The result revealed that age of the cassava farmers and farming experience were the inefficiency variables significantly determined farmer's technical efficiency. The study recommends policies that facilitate access to fertilizer and improved cassava cuttings will go a long way to improve the technical efficiency levels of farmers in the area.

\section{References}

Adebisi, A.O., Olajide, F.B., Adeoye, I.B. and Olajide, L.O. (2012). Analysis of Production constraints Facing Fadama Vegetable Farmers in Oyo State. World J. Agric. Sci., 7(2): 189-192.

Akatugba-Ogisi, O.D. (1994). Multiple Objectives and small Farmer Production Behaviour in Delta and Edo States of Nigeria: An application of Goal Programming. Unpublished Ph.D Thesis, Department of Agricultural Economics and Management, University of Reading, UK.

Agwu, A.E. and Anyaeche, C.L. (2007). Adoption of Improved Cassava Varieties in SixRural Communities of Anambra State, Nigeria, African Journal of Biotechnology, 6(2): 8998.

Awoyinka, Y.A., (2009). Effect of presidential initiatives on Cassava 
production efficiency in Oyo State Nigeria. Ozean Journal of Applied Sciences, 2(2): 185-193.

Bureau of African Affairs, 2010. Background Note: Nigeria. Retrieved from: http://www.state.gov/ r/pa/ei/bgn/2836.htm, (Accessed on: 01 November, 2010).

Chukwuji C.O. (2006) Factor Productivity and Technical Efficiency in Cassava based Food Crop Production Systems in Delta State, Nigeria. Unpublished Ph.D Thesis, Department of Agricultural Economics and Extension, Delta State University, Abraka, Nigeria

Federal Ministry of Agriculture and Rural Development (FMARD) (2006). National Programme for Food Security (NPFS) Expansion Phase Project 2006-2010 (Main Report). Nigeria.

FAO. (2007). Food and Agricultural Organization, Database Results.

Food and Agriculture Organization Statistical Database (FAOSTAT) (2009). Retrieved from: http://www. faostat.org/site/339/default.aspx.

National Population Commission (NPC). (2006).

Nandi, J.A., Gunn, P. and Yurkushi, E.N. (2011). Economic Analysis of Cassava Production in Obubra Local Government, Area of Cross River State, Nigeria Asian Journal of Agricultural Sciences, 3(3): 205-209.

Nwaiwu, I., Odii, M., Ohajianya, D., Eze, C., Oguoma, N., Ibekwe, C., HenriUkoha, A., Kadiri, F., Amaechi, C. and Oguh, J. (2010). Comparative Analysis of the Productivity of Sustainable Cassava Farming Under External And Internal Input Use in Imo State, Nigeria. New York Science Journal, 3(10): 12 -16.
Nweke F.I., Hahn, S.K and B.O. Ugwu, (1994). Circumstances of Rapid Spread of Cultivation of Improved Cassava Varieties in Nigeria. Journal of Farming System Research and Extension, 4(3): 93-119.

Ogisi, O.D., Begho, T. and Alimeke, B.O. (2013). Productivity and Profitability of Cassava (Manihot esculenta) In Ika South and Ika North East Local Government Areas of Delta State, Nigeria. IOSR Journal of Agriculture and Veterinary Science, 6(1): 52-56.

Olukosi, J.O. (1999). Participatory Approach to Household Food Production and Security. A paper presented at Society for International Development Seminar on Food Security, Social Mobilization and Community Empowerment. Held at Kongo Conference Hotel, Zaria, Kaduna State, Nigeria. Postgraduate College, Obafemi Awolowo University, Ile-Ife, Nigeria.

Owombo, P.T., Adiyeloja, D.K., Koledoye, G.F., Ijigbade, J.O and Adeagbo, M.A (2012). Gross Margin Analysis of Amaranth Vegetable Production in Ondo State, Nigeria: A Gender Perspective. Journal of Agriculture and Biodiversity Research, 1(6): 9196

Raw Material Research and Development Council (RMRDC), (2004). Report on Survey of Selected Agricultural Raw Materials In Nigeria. Abuja. pp 9\&74. Simonyan, J.B., Olukosi, J.O. and Omolehin, R.A. (2010). Socioeconomic determinants of farmers' participation in Fadama II project in Kaduna State, Nigeria. J. Food Fibre Prod., 3(1): 592-593.

World Bank (2002). Sourcebook for Poverty Reduction Strategies, Chapter 16 Urban Poverty, World Bank, Edited by Jeni Klugman. 
Table 1: Socio-economic Characteristics of Cassava farmers

\begin{tabular}{|c|c|c|}
\hline Variables & Frequency & Percent \\
\hline \multicolumn{3}{|l|}{ 1. Sex } \\
\hline Male & 91 & 58.7 \\
\hline Female & 64 & 41.3 \\
\hline Total & 155 & 100.0 \\
\hline \multicolumn{3}{|l|}{ 2. Age (years) } \\
\hline$<30$ & 49 & 31.6 \\
\hline $31-40$ & 39 & 25.2 \\
\hline $41-50$ & 37 & 23.9 \\
\hline $51-60$ & 24 & 15.5 \\
\hline$>60$ & 6 & 3.8 \\
\hline Total & 155 & 100.0 \\
\hline \multicolumn{3}{|l|}{ Mean $=39.8, S D=2.8$} \\
\hline \multicolumn{3}{|l|}{ 3. Farm Size (ha.) } \\
\hline$<0.6$ & 69 & 44.5 \\
\hline $0.6-1.0$ & 39 & 25.2 \\
\hline $1.1-1.5$ & 2 & 1.3 \\
\hline $1.6-2.0$ & 10 & 6.5 \\
\hline$>2.0$ & 35 & 22.5 \\
\hline Total & 155 & 100.0 \\
\hline \multicolumn{3}{|c|}{ Mean $=0.73 \mathrm{ha} ; \mathrm{SD}=0.11 \mathrm{ha}$} \\
\hline \multicolumn{3}{|c|}{ 4. Household Size } \\
\hline $1-4$ & 41 & 26.5 \\
\hline $5-6$ & 79 & 51.0 \\
\hline$\geq 7$ & 35 & 22.5 \\
\hline Total & 155 & 100.0 \\
\hline \multicolumn{3}{|l|}{ Mean $=6.0 ; \mathrm{SD}=0.01$} \\
\hline \multicolumn{3}{|c|}{ 5. Farming experience (Years) } \\
\hline$<6$ & 32 & 20.6 \\
\hline $6-10$ & 47 & 30.3 \\
\hline$>10$ & 76 & 49.1 \\
\hline Total & 155 & 100 \\
\hline \multicolumn{3}{|l|}{ Mean $=9.1, \mathrm{SD}=1.8$} \\
\hline \multicolumn{3}{|l|}{ 6. Marital Status } \\
\hline Married & 117 & 75.5 \\
\hline Single & 38 & 24.5 \\
\hline Total & 155 & 100 \\
\hline \multicolumn{3}{|c|}{ 7. Training on cassava farming } \\
\hline Yes & 41 & 26.5 \\
\hline No & 114 & 73.5 \\
\hline Total & 155 & 100 \\
\hline \multicolumn{3}{|l|}{ 8. Educational Level } \\
\hline No formal education & 33 & 21.3 \\
\hline Primary & 40 & 25.8 \\
\hline Secondary & 48 & 31.0 \\
\hline Tertiary & 34 & 21.9 \\
\hline Total & 155 & 100 \\
\hline \multicolumn{3}{|c|}{ 9. Contact with extension agent } \\
\hline Yes & 20 & 12.9 \\
\hline No & 135 & 87.1 \\
\hline Total & 155 & 100 \\
\hline
\end{tabular}


Table 2: Result of stochastic frontier model of cassava farmers

\begin{tabular}{llll}
\hline Variable & Coefficient & Standard Error & $\mathrm{t}$ value \\
\hline Constant & 0.3075 & 0.1140 & $2.6974^{* *}$ \\
Qty of cuttings & 0.4837 & 0.1304 & $3.7094^{* * *}$ \\
Qty of fert. & 0.6139 & 0.1579 & $3.8879^{* * *}$ \\
Farm Size & 0.4272 & 0.1339 & $3.1904^{* *}$ \\
Labour & -0.4621 & 0.3474 & $-1.3301^{\mathrm{NS}}$ \\
Man day & 0.4441 & 0.3215 & $1.3814^{\mathrm{NS}}$ \\
Inefficiency & & & \\
Constant & 0.1182 & 0.8761 & 0.1349 \\
Age & 0.8342 & 0.4223 & $1.9754^{*}$ \\
Household size & 0.5750 & 0.6370 & $0.0090^{\mathrm{NS}}$ \\
Farming Experience & -0.5819 & 0.1834 & $-3.1728^{* *}$ \\
Years spent in school & 0.1982 & 0.9618 & $0.2061^{\mathrm{NS}}$ \\
Extension contact & -0.2419 & 0.1621 & $-1.4922^{\mathrm{NS}}$ \\
\hline Mens & &
\end{tabular}

Mean efficiency $=0.68538 \mathrm{E}+00$

$\sigma^{2}=0.5226 \mathrm{E}+01 ;(\gamma)=0.3289 \mathrm{E}+00$

Log-likelihood function $=-0.7243 \mathrm{E}+02$

$* *=5 \%$ significant, $*=10 \%$ significant $\mathrm{NS}=$ Not significant

Table 3: Frequency Distribution of Technical Efficiency Indices

\begin{tabular}{lll}
\hline Technical Efficiency Range & Frequency & Percent \\
\hline $0.31-0.40$ & 10.0 & 6.5 \\
$0.41-0.50$ & 17.0 & 10.9 \\
$0.51-0.60$ & 22.0 & 14.2 \\
$0.61-0.70$ & 40.0 & 25.8 \\
$0.71-0.80$ & 28.0 & 18.1 \\
$0.81-0.90$ & 30.0 & 19.4 \\
$0.91-1.00$ & 8.0 & 5.1 \\
Total & 155.0 & 100 \\
\hline Min & 0.35 & \\
Max & 0.97 & \\
Mean efficiency $=0.685$ & & \\
\hline
\end{tabular}

